\title{
Immunological Study of Interleukin-2 in the Patients with Malignant Brain Tumors
}

\author{
Seiichi YoSHIDA, Ryuichi TANAKA and Nobuyuki TAKAI \\ Department of Neurosurgery, Brain Research Institute, Niigata University, Niigata
}

\begin{abstract}
The authors studied the capacity of peripheral blood lymphocytes from patients with malignant brain tumors to produce, and to respond to, interleukin-2 (IL-2). The role of IL-2 in generation of T cells cytotoxic to tumor cells was also studied. Lymphocytes from the patients with malignant brain tumors produced less IL-2 than did those of normal controls. However, phytohemagglutinin-activated peripheral blood lymphocytes from normal controls and the patients responded equally well to IL-2. This indicates that IL-2 receptors are abundant in the patients' lymphocytes, although IL-2 production may be depressed. Furthermore, after incubation with IL-2, lymphocytes from patients with malignant glioma exhibited higher natural killer activity and strong cytotoxicity to glioma cells. Its tumor cell cytotoxicity makes IL-2 a likely candidate for use in adoptive immunotherapy.
\end{abstract}

Key words: malignant glioma, interleukin-2, adoptive immunotherapy

\section{Introduction}

It was recently reported that several soluble factors are associated with the proliferation and differentiation of $\mathrm{T}$ lymphocytes. Interleukin-2 ( $\mathrm{T}$ cell growth factor, IL-2) is one of these immunoregulatory factors. Human IL-2, a 13,500 MW factor, is released by stimulated $\mathrm{T}$ cells and is required for the clonal proliferation of activated T lymphocytes. Moreover, IL-2 is capable of promoting and maintaining continuous growth of cytotoxic $\mathrm{T}$ cell lines, ${ }^{12)}$ and it has been tried as an adoptive immunotherapy in cancer patients. $^{\text {(i) }}$

In an attempt to better understand the suppression of cell-mediated immunity in patients with malignant brain tumors, ${ }^{2)}$ we studied the production of, and the response to, IL-2 in such patients. We also studied IL-2-induced tumor cell cytotoxicity by examining IL-2 biological function during immune surveillance for brain tumors.

\section{Patients and Methods}

The study involved 28 patients with malignant gliomas, 26 with metastatic brain tumors, five with neurinomas, and seven with meningiomas. Their

Received November 25, 1986; Accepted December 14,1987 ages ranged from 47 to 61 years.

Peripheral blood lymphocytes (PBL) were obtained by Ficoll gradient centrifugation ${ }^{1)}$ and were resuspended in RPMI 1640 (GIBCO, Grand Island, NY).

\section{IL-2 production}

PBL $\left(1 \times 10^{6} / \mathrm{ml}\right)$ were stimulated with $1 \mu \mathrm{g} / \mathrm{ml}$ phytohemagglutinin (PHA-P) (Burroughs Wellcome, Greenville, NC) in tissue culture plates for 24 hours at $37^{\circ} \mathrm{C}$ in an atmosphere of $5 \% \mathrm{CO}_{2}$. Culture supernatants were collected by centrifugation of the cell suspensions at $200 \mathrm{gm}$ for 10 minutes followed by filtration through millipore filters with $0.22-\mu \mathrm{m}$ pores (Bedford, MA). To each sample, $100 \mu \mathrm{l} /$ well of $1 \times 10^{4} \mathrm{CTLL}$ cells (IL-2-dependent PBL) were added, and incubated for 24 hours at $37^{\circ} \mathrm{C}$ in air containing $5 \% \mathrm{CO}_{2}$. Following pulsation with $0.5 \mu \mathrm{Ci}$ $\left[{ }^{3} \mathrm{H}\right]$ thymidine for 4 hours, the cells were collected by a cell harvester and counted by a Beckman liquid scintillation counter.

\section{Response to IL-2}

For generation of IL-2 receptors, PBL from both the patients and control subjects were incubated with PHA-P $(10 \mu \mathrm{g} / \mathrm{ml})$ for 48 hours at $37^{\circ} \mathrm{C}$. The cells were then washed, cultured with standard IL-2 (Associated Biomedic Systems Inc., Buffalo, NY), and treated with $0.5 \mu \mathrm{Ci}$ of $\left[{ }^{3} \mathrm{H}\right]$ thymidine. Four hours later, $\left[{ }^{3} \mathrm{H}\right]$ thymidine uptake was measured as de- 
scribed above. ${ }^{4)}$

\section{Effects of IL-2 on natural killer cell activity} and cytotoxicity to tumor cells

K562, a myeloid leukemia cell line sensitive to natural killer (NK) cells, and NP-1, an established human glioma cell line, were exposed to $400 \mu \mathrm{Ci}$ of $\mathrm{Na}^{51} \mathrm{CrO}_{4}$ (Amersham Corporation, Arlington Heights, IL) for 80 minutes. PBL cocultured with IL-2 were washed and tested for their ability to lyse these ${ }^{51} \mathrm{Cr}$-labeled target cells ${ }^{7}$ at various effector-totarget cell ratios by the 4 -hour ${ }^{51} \mathrm{Cr}$ release assay. Lysis of the target cells was quantitated as percent specific lysis, as follows:

$$
\begin{aligned}
& \% \text { specific lysis }= \\
& \quad \frac{\text { experimental } \mathrm{cpm}-\text { spontaneous } \mathrm{cpm}}{\text { maximal } \mathrm{cpm}-\text { spontaneous } \mathrm{cpm}} \times 100
\end{aligned}
$$

where spontaneous release is determined without effector cells and maximal release is determined by the use of detergents (cpm $=$ counts per minute).

In vitro sensitization and activation of lymphokine-activated killer cells: PBL from the patients were incubated in PRMI $1640\left(5 \times 10^{6} / \mathrm{ml}\right)$ and $0.2 \%$ PHA-P for 2 days. IL-2 was added to the PBL $\left(1 \times 10^{6} / \mathrm{ml}\right)$, and sensitization was accomplished by coculturing for 4 days.

\section{Results}

\section{IL-2 production}

IL-2 was generated in cultures of PBL stimulated with PHA-P and the results are summarized in Fig. 1. In cultures of PBL from patients with malignant gliomas and metastatic brain tumors, mean $\left[{ }^{3} \mathrm{H}\right]$ thymidine uptake was $17,200 \pm 4100$ and $16,800 \pm 4250$ $\mathrm{cpm}$, respectively, whereas in the control samples it was $21,900 \pm 3600 \mathrm{cpm}$. Thus, PBL of patients with malignant brain tumors produced lower than normal amounts of IL-2 $(\mathrm{p}<0.01)$. The decreased IL-2 production was not correlated with other immunological parameters, such as lymphocyte blastogenesis or immunosuppressive acid protein. In patients whose tumors had advanced despite treatment and those with end-stage disease, the suppression of IL-2 production was marked. Continued tumor growth and increasing severity of neurological deficits were paralleled by progressive reduction in IL-2 production. Since IL-2 is a lymphokine produced by activated T cells, the deficiency of IL-2 production in these patients appeared to be a consequence of the decrease in the IL-2-producing $\mathrm{T}$ cell population.

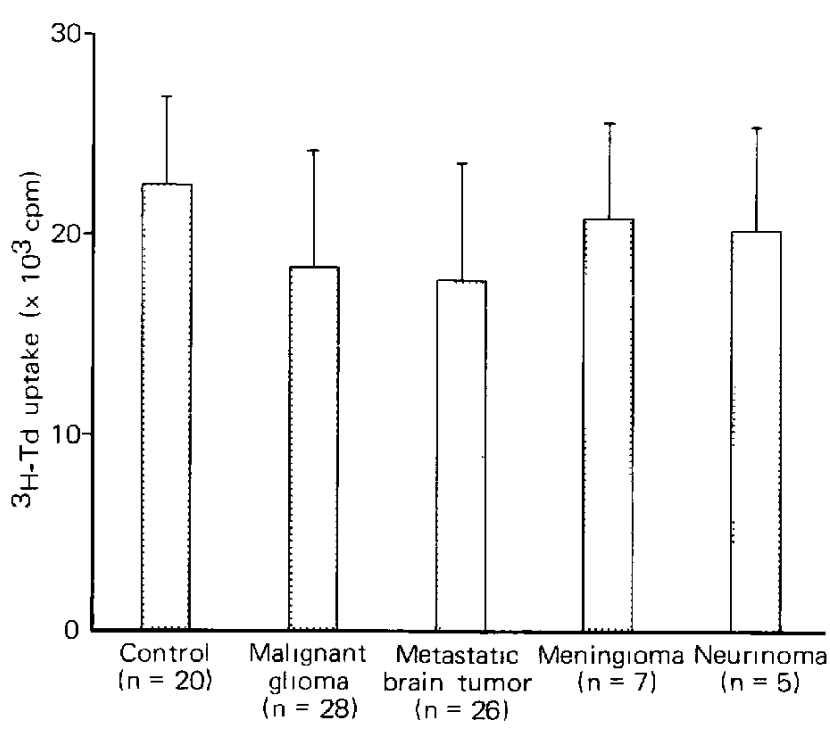

Fig. 1 Production of IL-2 by $\mathrm{T}$ cells from patients with malignant brain tumors. IL-2 was measured by addition of the supernatant to cultured cells that had first been stimulated for 24 hours with PHA-P and maintained for 24 hours with IL-2. IL-2 production in patients was lower than that in normal individuals. ${ }^{3} \mathrm{H}-\mathrm{Td}$ : $\left[{ }^{3} \mathrm{H}\right]$ thymidine. We present mean and $\mathrm{SD}$.

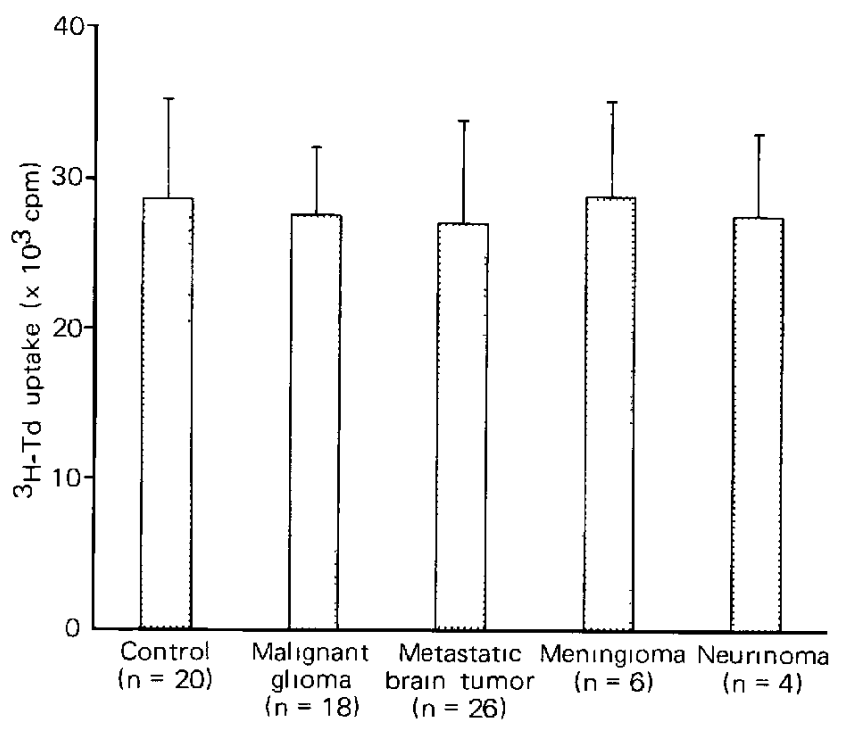

Fig. 2 Response to IL-2 by PBL from patients with malignant brain tumors. PBL stimulated for 48 hours with PHA-P were used as indicator cells in the IL-2 assay. The PBL blast response to IL-2 did not significantly differ between the normal controls and the patients. 


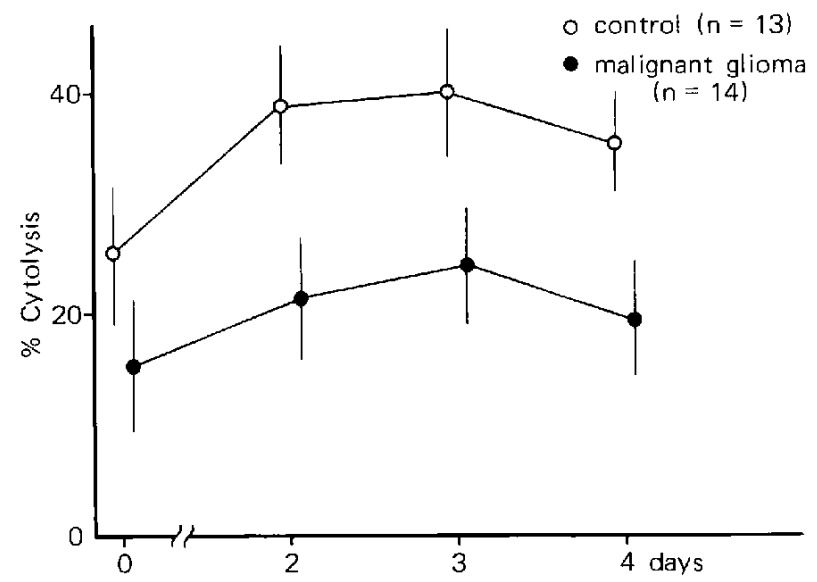

Fig. 3 Effects of IL-2 on NK cell activity. PBL from 14 glioma patients and 13 normal individuals were cultured in IL-2 for 4 days and tested for lysis of K562. All assays were performed for 4 hours at an effector-to-target ratio of 10:1. NK cell lysis of K562 was higher in the control groups, but not so evident in the patients with malignant glioma.

\section{Response to IL-2}

PHA-P-activated PBL from the patients with malignant brain tumors responded normally to standard IL-2 (Fig. 2). Mean $\left.{ }^{3} \mathrm{H}\right]$ thymidine uptake was $27,400 \pm 4100 \mathrm{cpm}$ in the control samples and $26,800 \pm 3800$ and $26,400 \pm 3400 \mathrm{cpm}$, respectively, for patients with malignant gliomas and metastatic brain tumors. This result indicates that these patients have sufficient IL-2 receptors. There was no relationship between IL-2 responsiveness and lymphocyte blastogenesis.

\section{Effects of IL-2 on NK activity and cytotoxicity to tumor cells}

PBL from 14 glioma patients were tested for lysis of the known NK-sensitive target cell, K562, and the human glioma cell, NP-1. The cytotoxicity of these PBL to K562 and NP-1 was $15.2 \pm 7.5 \%$ and $26.8 \pm 11.4 \%$, respectively. This finding suggests that PBL from glioma patients contain NK cells, but that these cells are incapable of substantial tumor cell lysis. In the next phase, the PBL were activated with IL-2 and tested for lysis of the tumor cells. After incubation with IL-2, PBL were strongly cytotoxic to both $\mathrm{K} 562(28.5 \pm 10.9 \%)$ and NP-1 $(35.4 \pm 12.1 \%)$. This increased cytotoxicity, which included NK cell activity, was evident by day 2 or 3 of culture with IL-2 and persisted until at least day 4 (Figs. 3 and 4).

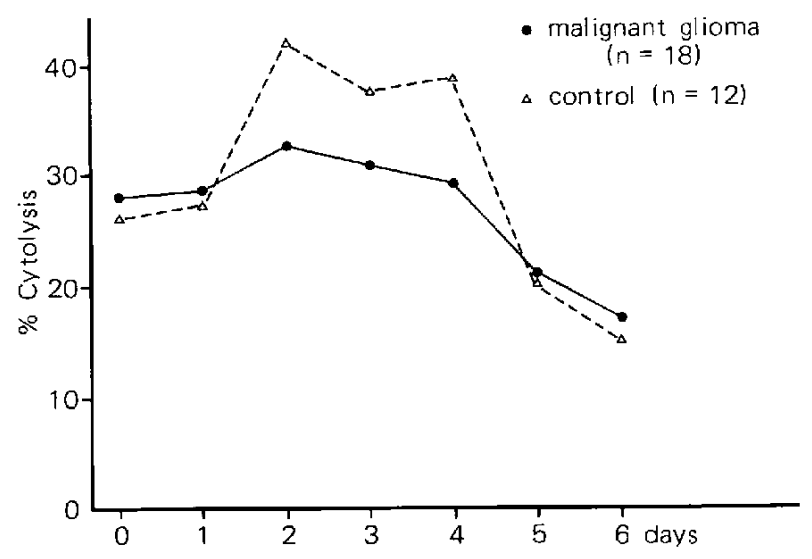

Fig. 4 Kinetics of the development of lymphokine-activated killer cells. PBL from the patients with malignant gliomas and normal individuals were tested for lysis of glioma cells (NP-1) and for the development of lysis. All tests involved the 4-hour ${ }^{51} \mathrm{Cr}$ release assay, and the data are for an effector-to-target ratio of 10:1. Lytic activity evidently increased by day 2 or 3 of culture with IL-2 and persisted until day 4.

\section{Discussion}

Production of IL-2 has been attributed to Lyt-1 ${ }^{+} \mathrm{T}$ cells in mice ${ }^{8)}$ and to OKT $4^{+} 8^{+} \mathrm{T}$ cells in humans. ${ }^{10,11)}$ The Lyt $1^{+}$and OKT $4^{+}$populations exhibit the phenotypic characteristics of helper $T$ cells. Using these monoclonal antibodies, we studied $T$ cell subsets in patients with malignant brain tumors and concluded that these patients had almost normal numbers of helper $T$ cells. However, in this study we found a deficit in the production of IL-2 by PBL of patients with malignant brain tumors. In some patients, the reduction in IL-2 activity was correlated with the clinical stage. Therefore, we considered several mechanisms by which IL-2 deficiency might arise. First, since IL-2-producing $T$ cells are partially activated by signals from macrophages, macrophage malfunction could be the cause of decreased IL-2 production. ${ }^{3)}$ Second, soluble inhibitor or suppressor cells may decrease IL-2 activity. ${ }^{13)}$ Third, a functional abnormality of IL-2-producing cells might result in lowered IL-2 production.") There may be other possible mechanisms. In any event, the response of PHA-P-activated cells to standard IL-2 was almost normal, indicating that the mechanism by which IL-2 receptors are activated was intact in PBL of the patients with malignant glioma.

Age and corticosteroid therapy may affect the production of and the response to IL-2; ${ }^{5)}$ however, in 
our study the mean ages of the controls and patients were similar, and only four of the 66 patients were receiving steroids.

The results of this study suggest that suppression of IL-2 production may contribute to the impairment of immunoregulation in patients with malignant brain tumors. Further study is needed to identify the mechanisms responsible for these changes. Also, PBL from patients with gliomas could be induced, through exposure to IL-2, to kill tumor cells. This cytolytic system differs from the NK cell and classical cytotoxic lymphocyte systems, and the tumor cytotoxicity makes it a likely candidate for use in adoptive immunotherapy.

\section{References}

1) Böyum A: Separation of leucocytes from blood and bone marrow. Scand J Clin Lab Invest 21 [Suppl] 97: 7, 1968

2) Brooks WH, Netsky MG, Normansell DE, Horwitz DA: Depressed cell-mediated immunity in patients with primary intracranial tumors. J Exp Med 136: $1631-1647,1972$

3) Farrar JJ, Mizel SB, Fuller-Farar J, Farrar WL, Hilfiber ML: Macrophage-independent activation of helper T cells. I. Production of interleukin 2. $J \mathrm{Im}$ munol 125: 793-798, 1980

4) Gillis $S$, Ferm MM, Ou W, Smith KA: T cell growth factor. Parameters of production and a quantitative microassay for activity. $J$ Immunol 120: 2027-2032, 1978

5) Gillis S, Kozak R, Durante M, Weksler ME: Immunological studies of aging. Decreased production of and response to $\mathrm{T}$ cell growth factor by lymphocytes from aged humans. $J$ Clin Invest 67: 937942, 1981
6) Gillis S, Mochizuki DY, Conlon PJ, Hefeneider SH, Ramthum CA, Gillis AE, Frank MB, Henney CS, Watson JD: Molecular characterization of interleukin 2. Immunol Rev 63: 167-209, 1982

7) Grimm EA, Mazumder A, Zhang HZ, Rosenberg SA: Lymphokine-activated killer cell phenomenon. Lysis of natural killer-resistant fresh solid tumor cells by interleukin 2-activated autologous human peripheral blood lymphocytes. $J$ Exp Med 155: 1823-1841, 1982

8) Lattime EC, Gillis S, Decoraro G, Stutman O: Iadependent interleukin 2 production in syngeneic cellular interactions. $J$ Immunol 128: 480-485, 1982

9) Linker-Israeli M, Bakke AC, Kitridou RC, Gendler S, Gillis S, Horwitz DA: Defective production of interleukin 1 and interleukin 2 in patients with systemic lupus erythematosus (SLE). J Immunol 130: 16511655,1983

10) Luger TA, Smolen JS, Chused TM, Steinberg AD, Oppenheim JJ: Human lymphocytes with either the OKT4 or OKT8 phenotype produce interleukin 2 in culture. $J$ Clin Invest 70: 470-473, 1982

11) Palacios R: Concanavalin A triggers $T$ lymphocytes by directly interacting with their receptors for activation. J Immunol 128: 337-342, 1982

12) Smith KA, Gillis S, Baker PE, McKenzie D, Ruscetti FW: T-cell growth factor-mediated T-cell proliferation. Ann NY Acad Sci 332: 423-432, 1979

13) Wofsy D, Murphy ED, Roths JB, Dauphinée MJ, Kipper SB, Talal N: Deficient interleukin 2 activity in $\mathrm{MRL} / \mathrm{Mp}$ and $\mathrm{C} 57 \mathrm{BL} / 6 \mathrm{~J}$ mice bearing the $/ p r$ gene. $J$ Exp Med 154: 1671-1680, 1981

Address reprint requests to: S. Yoshida, M.D., Department of Neurosurgery, Brain Research Institute, Niigata University, 757 Ichiban-cho, Asahimachidori, Niigata 951, Japan. 